\title{
Article \\ New Functionalized Macroparticles for Environmentally Sustainable Biofilm Control in Water Systems
}

\author{
Ana C. Barros ${ }^{1, *}$, Ana Pereira ${ }^{1}$, Luis F. Melo ${ }^{1}$ (D) and Juliana P. S. Sousa ${ }^{2}$ \\ 1 LEPABE - Laboratory for Process Engineering, Environment, Biotechnology and Energy, Faculty of \\ Engineering, University of Porto, 4200-465 Porto, Portugal; aalex@fe.up.pt (A.P.); lmelo@fe.up.pt (L.F.M.) \\ 2 INL, International Iberian Nanotechnology Laboratory, Avenida Mestre José Veiga s/n, \\ 4715-330 Braga, Portugal; juliana.sousa@inl.int \\ * Correspondence: acbarros@fe.up.pt; Tel.: +351-22-508-3603
}

check for updates

Citation: Barros, A.C.; Pereira, A.; Melo, L.F.; Sousa, J.P.S. New Functionalized Macroparticles for Environmentally Sustainable Biofilm Control in Water Systems. Antibiotics 2021, 10, 399. https://doi.org/ 10.3390/antibiotics10040399

Academic Editor: Carlos M. Franco

Received: 2 March 2021

Accepted: 3 April 2021

Published: 7 April 2021

Publisher's Note: MDPI stays neutral with regard to jurisdictional claims in published maps and institutional affiliations.

Copyright: (C) 2021 by the authors. Licensee MDPI, Basel, Switzerland. This article is an open access article distributed under the terms and conditions of the Creative Commons Attribution (CC BY) license (https:// creativecommons.org/licenses/by/ $4.0 /)$.

\begin{abstract}
Reverse osmosis ( $\mathrm{RO}$ ) depends on biocidal agents to control the operating costs associated to biofouling, although this implies the discharge of undesired chemicals into the aquatic environment. Therefore, a system providing pre-treated water free of biocides arises as an interesting solution to minimize the discharge of chemicals while enhancing RO filtration performance by inactivating bacteria that could form biofilms on the membrane system. This work proposes a pretreatment approach based on the immobilization of an industrially used antimicrobial agent (benzalkonium chloride-BAC) into millimetric aluminum oxide particles with prior surface activation with DA—dopamine. The antimicrobial efficacy of the functionalized particles was assessed against Escherichia coli planktonic cells through culturability and cell membrane integrity analysis. The results showed total inactivation of bacterial cells within five min for the highest particle concentration and $100 \%$ of cell membrane damage after $15 \mathrm{~min}$ for all concentrations. When reusing the same particles, a higher contact time was needed to reach the total inactivation, possibly due to partial blocking of immobilized biocide by dead bacteria adhering to the particles and to the residual leaching of biocide. The overall results support the use of $\mathrm{Al}_{2} \mathrm{O}_{3}$-DA-BAC particles as antimicrobial agents for sustainable biocidal applications in continuous water treatment systems.
\end{abstract}

Keywords: biocidal particles; functionalization; benzalkonium chloride; Escherichia coli; antimicrobial activity

\section{Introduction}

The so-called clean water crisis, which already affects near four billion people [1], is a major humanitarian issue. The effect of unbalanced urbanization, population growth and inadequate use of water is expected to increase between 22\% and 34\% until 2050 [1]. The requalification or reuse of water from non-potable sources is considered one of the most promising and attractive ways to face such water crisis, with special emphasis on the use of Reverse Osmosis (RO) systems to accomplish proper water "purification".

Biofouling - the attachment and accumulation of unwanted microorganisms in the form of a biofilm to an extent that interferes negatively with the filtration process [2] -is a major factor contributing to the decrease of the operational performance of RO systems. It is widely consensual that biofouling in $\mathrm{RO}$ systems is the main responsible for the decrease in permeate flow rate and quality, increase of pressure drop and of energy demand [3]. Since biofilm build-up is still practically unavoidable, new and sustainable approaches are needed to circumvent this issue [4].

The use of antimicrobial agents, typically disinfectants and/or biocides, is a challenging question across the water treatment sector. On one hand, antimicrobial agents per se are not always able to eradicate biofouling, nor have a similar killing effect on planktonic and sessile (attached) bacteria [5,6]. Additionally, the use of antimicrobial agents dissolved in the water is known to have a negative impact on process economy, 
health and environment, mostly associated with their discharge along with the rejection stream [7]. On the other hand, it is generally accepted that biocides are important to control microbiological proliferation. They became a "must have" feature to include in RO systems and are used not only in corrective procedures but, also, in routine-based operations [8].

This paradigm opened an opportunity to explore different ways of keeping systems microbiologically controlled while reducing the environmental and public health impacts associated with the use of biocides as a daily-basis procedure. The rise of nanotechnology and the possibility to aggregate new physicochemical properties to the materials in terms of surface area, topography and chemical function [9] is being extensively explored to fulfil this challenge. Several of the approaches that are being investigated include the development of materials with self-antimicrobial properties-e.g., nano-Ag, nano$\mathrm{ZnO}$, etc. [10-18] — and the immobilization of biocidal agents on nanostructured materials due to their high surface-area-to-volume ratio and surface modifiability [19-22]. These materials can be used as adsorbents of pollutants or as carriers for the biocidal agent. However, serious environmental and health concerns are arising about the fate and toxicity of nanoparticles in water systems [23].

In the present work, a different approach is proposed: (i) the antimicrobial particles are pellets with overall millimetric size, which can be packed in a particle bed system through which the water containing microorganisms flows continuously; (ii) due to their relatively larger dimensions $\left(10^{6}\right.$ times the size of nanomaterials), these particles can be easily contained in a vessel and not carried away with the outlet water stream. As regards the composition of the particles, metal oxides were chosen, since they have already been successfully applied for environmental monitoring, remediation and pollution prevention [24] and have a low cost. Commercial metal oxides, namely $\gamma$-alumina, present excellent mechanical and chemical properties; however, their surface chemical properties do not favor the direct immobilization of biocides. Therefore, it is necessary to previously activate the surfaces to increase their surface reactivity. Herein, an easy and reproducible approach to immobilize biocides onto the surface of metal oxides is proposed. First, the metal oxide particles are functionalized with a precursor to activate their surface reactivity and then the biocide is immobilized onto the surface by putting the metal oxide particles in contact with the biocidal solution.

In this work, alumina particles were functionalized by using a nitrogen precursor (Dopamine (DA)). Subsequently, the biocide benzalkonium chloride (BAC) was immobilized in these particles, and their antimicrobial activity was assessed against Escherichia coli bacteria in planktonic state. BAC is a cationic surfactant, belonging to the family of QACs (quaternary ammonium compounds), with antibacterial properties often used in water treatment [25]. BAC gathered the attention of the scientific community because of its physical-chemical characteristics [26] and its mechanisms of interaction with bacteria [27], later discussed in the Results and Discussion section of the present paper. Several studies regarding the immobilization of QAC compounds in nanostructured material were published [22], including the functionalization of metal oxide nanoparticles [28,29]. However, none of those cases include the functionalization of macroscopic metal oxide pellets.

The present work is the first step to pursue the incorporation of antimicrobial macroscopic particles into a continuous flow bed-reactor (fixed or fluidized) to be added as an RO pretreatment step of a water stream. The success of this approach will contribute to optimize the application of biocides while minimizing the environmental and health impacts. Therefore, the solution here proposed considers the use of commercially available metal oxides (pellet shape, overall average dimension of $3 \mathrm{~mm}$ ) with added biocidal properties, overcoming two issues brought by real-field applications of nanoparticles: the difficulty in removing nanoparticles from industrial-scale water streams and the high pressure drop caused by the compaction of a bed of nanoparticles. 


\section{Results and Discussion}

\subsection{Functionalization Characteristics}

In order to activate the surface of alumina samples, the commercial materials were functionalized with a nitrogen precursor, namely dopamine. The nitrogen groups introduced in the particles' surface act as anchorage points to immobilize the biocide. The prepared materials were characterized using different techniques, yielding the results described in the next subtopics.

\subsubsection{Thermal Stability of Functionalized Metal Oxides}

To get more insight into the packing density, thermogravimetric analysis was used to estimate the amount of functional groups anchored to the surface of the particles (Figure 1). By observing the weight loss profiles of the raw material $\left(\mathrm{Al}_{2} \mathrm{O}_{3}\right)$, it appears that the latter does not have organic impurities, because the values of burn-off obtained for these samples are very low $(3 \%)$, see Figure $1 \mathrm{a}$.

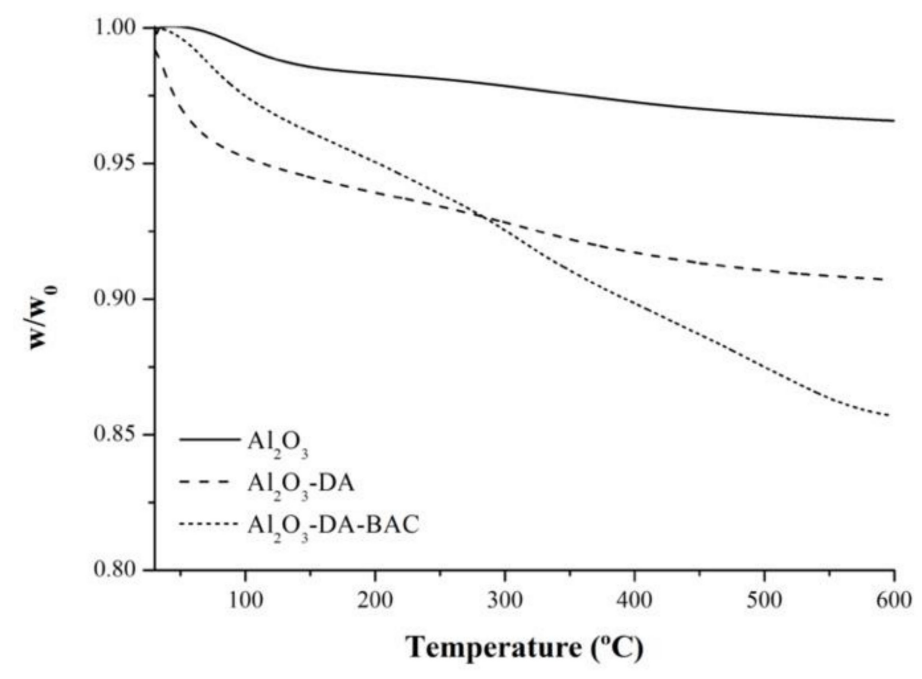

(a)

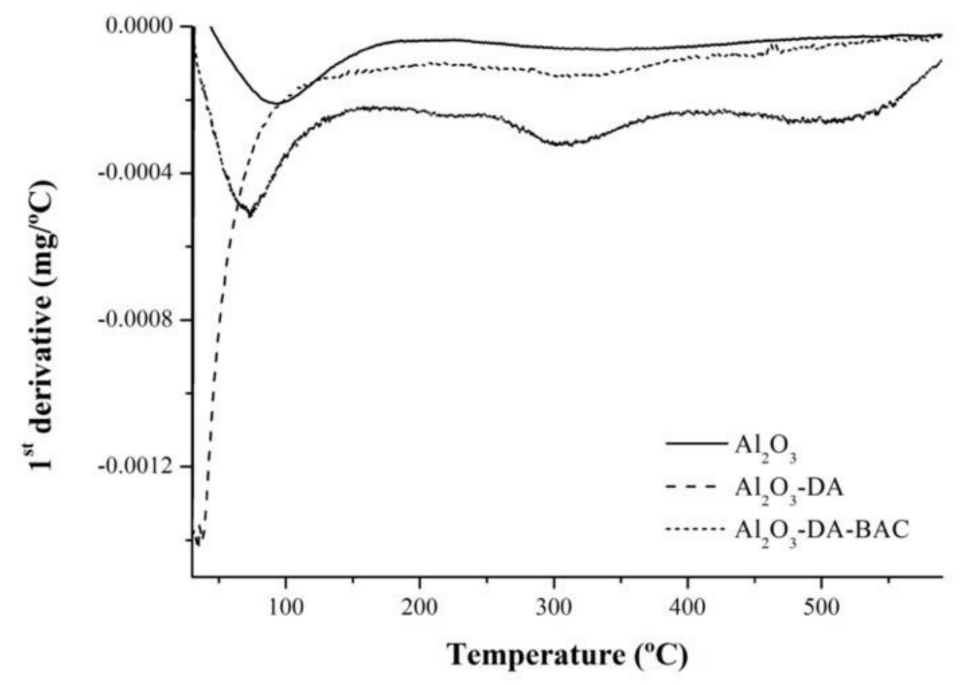

(b)

Figure 1. Thermogravimetric analysis, TG (a) and first derivative curve, DTG (b) of functionalized and $\mathrm{Al}_{2} \mathrm{O}_{3}$ particles. 
The functionalization with nitrogen precursors increased the values of the burnoff. The sample $\mathrm{Al}_{2} \mathrm{O}_{3}$-DA present weight losses between 200 and $400{ }^{\circ} \mathrm{C}$ of around $2 \%$. The thermogravimetric analysis (Figure 1a) confirmed the success of the functionalization with nitrogen precursors. The interaction between dopamine and inorganic materials is most likely due to hydrogen bonding, conferring a high thermal stability to the sample.

The nitrogen groups introduced in alumina particles by dopamine will be the anchor points for BAC immobilization. It can be seen in Figure $1 \mathrm{~b}$ that the $\mathrm{Al}_{2} \mathrm{O}_{3}$-DA-BAC sample presents a total mass loss of $3 \%$ in the temperature ranges of $280-390{ }^{\circ} \mathrm{C}$ and $426-598^{\circ} \mathrm{C}$. This 3\% corresponds to the amount of immobilized BAC per unit mass of particles, as described in Section 3.4.3.

\subsubsection{Adsorption/Desorption Isotherms}

Adsorption and desorption isotherms of the particles were performed. As can be seen in Figure 2, all particles showed a type IV isotherm behavior, which indicates the presence of mesopores [30-32].

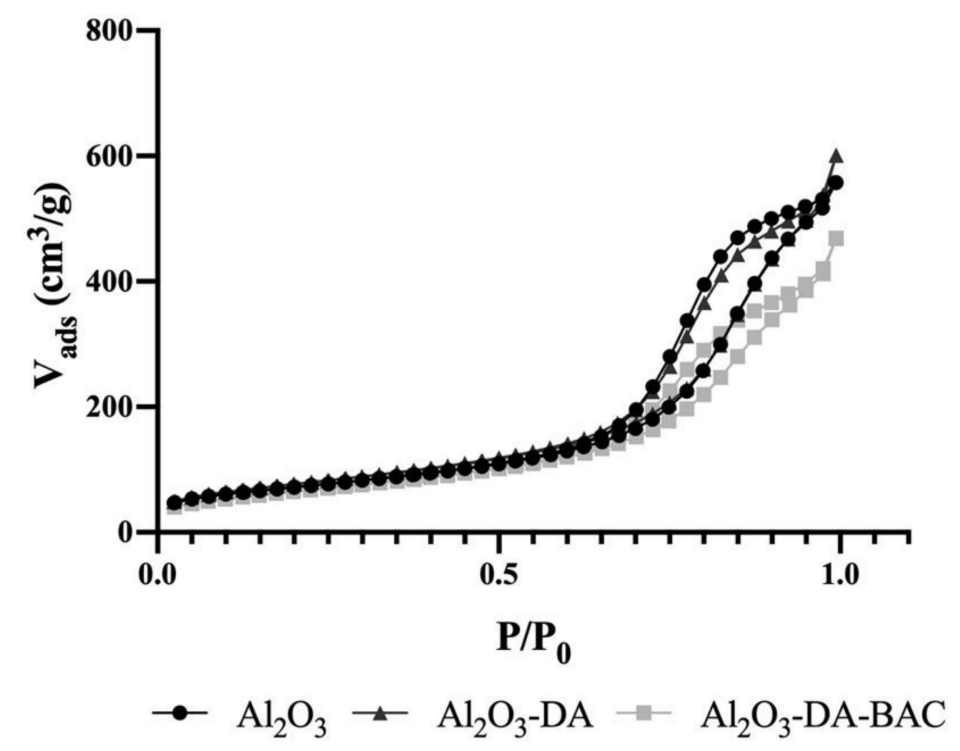

Figure 2. Nitrogen adsorption and desorption isotherms of functionalized and $\mathrm{Al}_{2} \mathrm{O}_{3}$ particles.

Table 1 summarizes the results obtained from nitrogen adsorption-desorption isotherms (Figure 2). According to the $\mathrm{N}_{2}$ physisorption, it appears that the functionalization treatment changed the textural properties of alumina materials. The surface area of the sample treated with dopamine increases after the treatment (from 258 to $280 \mathrm{~m}^{2} / \mathrm{g}$ ). The development of porosity during the treatment with dopamine (Table 1), observed for the alumina materials, is due to the widening of existing pores $\left(\mathrm{d}_{\mathrm{p}}\right.$ increased from 8.2 to $\left.9.0 \mathrm{~nm}\right)$, confirming the successful functionalization of this material. This can be explained by the fact that the dopamine solution has a high $\mathrm{pH}$ value (basic solution), which can cause some dissolution/etching of the aluminum oxide. After the BAC immobilization, the surface area of this sample decreased to $240 \mathrm{~m}^{2} / \mathrm{g}$ which can be explained by the occupation of some pores by the BAC molecules, since the pore volume decreased from 0.77 to $0.60 \mathrm{~cm}^{3} / \mathrm{g}$. 
Table 1. Surface area parameters obtained for the functionalized particles and the control $\left(\mathrm{Al}_{2} \mathrm{O}_{3}\right)$.

\begin{tabular}{cccc}
\hline Sample & $\mathbf{S}_{\mathbf{B E T}}\left(\mathbf{m}^{2} / \mathbf{g}\right)$ & $\mathbf{d}_{\mathbf{p}}(\mathbf{n m})$ & $\mathbf{V}_{\mathbf{p 0 : 0 . 9 5}}\left(\mathbf{c m}^{3} / \mathbf{g}\right)$ \\
\hline $\mathrm{Al}_{2} \mathrm{O}_{3}$ & 258 & 8.2 & 0.77 \\
\hline $\mathrm{Al}_{2} \mathrm{O}_{3}$-DA & 280 & 9.0 & 0.77 \\
\hline $\mathrm{Al}_{2} \mathrm{O}_{3}$-DA-BAC & 240 & 8.1 & 0.60 \\
\hline \multicolumn{4}{c}{}
\end{tabular}

\subsubsection{X-ray Diffraction (XRD) Analysis}

The XRD pattern of the alumina particles is represented in Figure 3. The original alumina patterns show relatively strong peaks at $2 \theta$ values at $28,38,49,65$ and $72^{\circ}$, which are attributed to the reflections of Boehmite $(\gamma-\mathrm{AlO}(\mathrm{OH}))$. The DA-functionalized sample presents a crystalline phase of $\eta-\mathrm{Al}_{2} \mathrm{O}_{3}$, detected by the presence of peaks at 37, 39, 46 and $67^{\circ}$. Additionally, $\mathrm{Al}_{2} \mathrm{O}_{3}$-DA-BAC particles show an entire transformation to $\gamma-\mathrm{Al}_{2} \mathrm{O}_{3}$, detected by the presence of two peaks at 47 and $68^{\circ}$. Data from the XRD also confirms the successful functionalization of the particles with biocide.

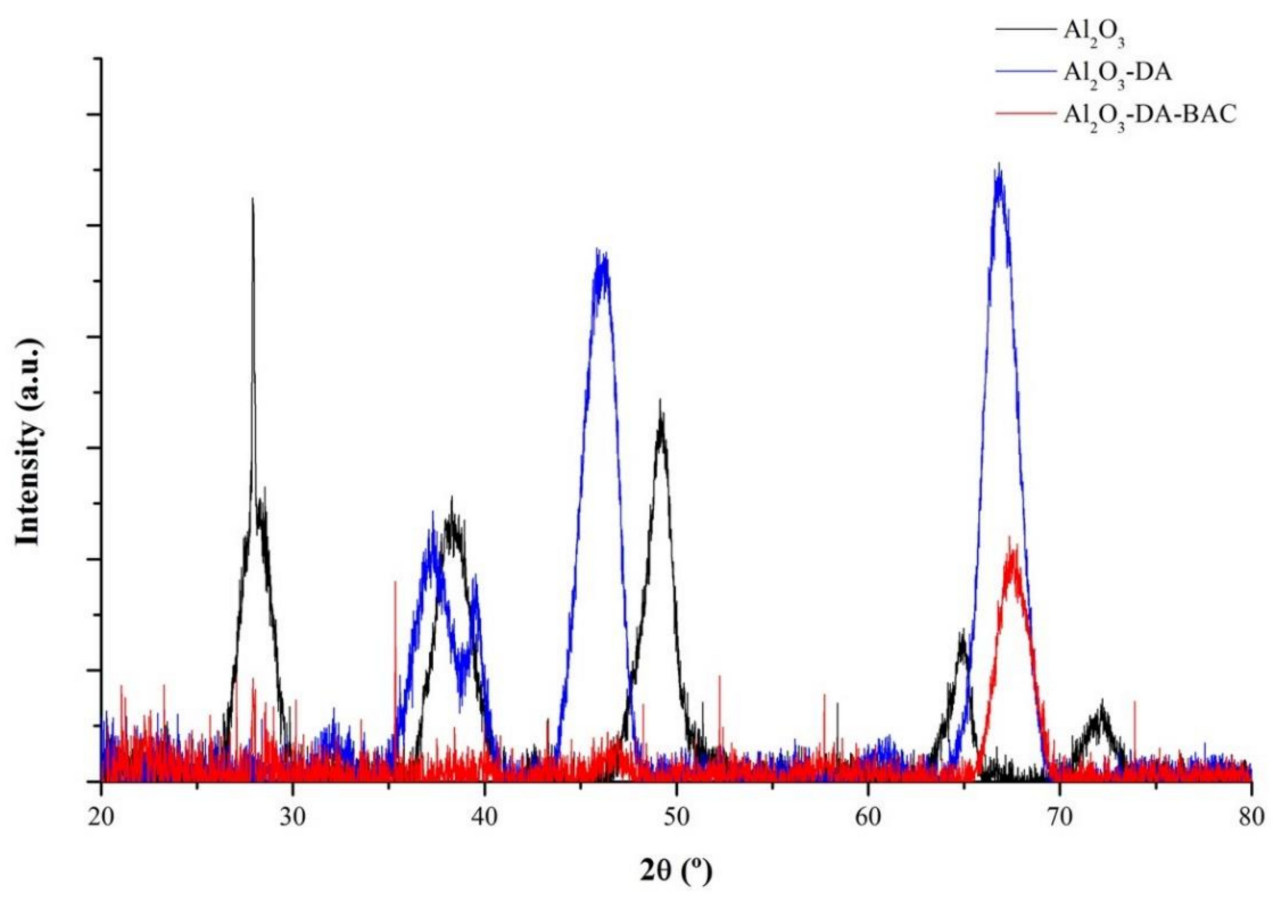

Figure 3. X-ray diffraction (XRD) pattern of functionalized and $\mathrm{Al}_{2} \mathrm{O}_{3}$ particles.

\subsubsection{Point of Zero Charge $-\mathrm{pH}_{\mathrm{PZC}}$}

Figure 4 shows the $\mathrm{pH}_{\mathrm{PZC}}$ values estimated for the alumina samples (prior to functionalization), which is found to be 5.7. This value increases to 7.3 after introduction of $-\mathrm{NH}_{2}$ groups, suggesting that the metal oxide surfaces have been modified with positively charged amino groups. 


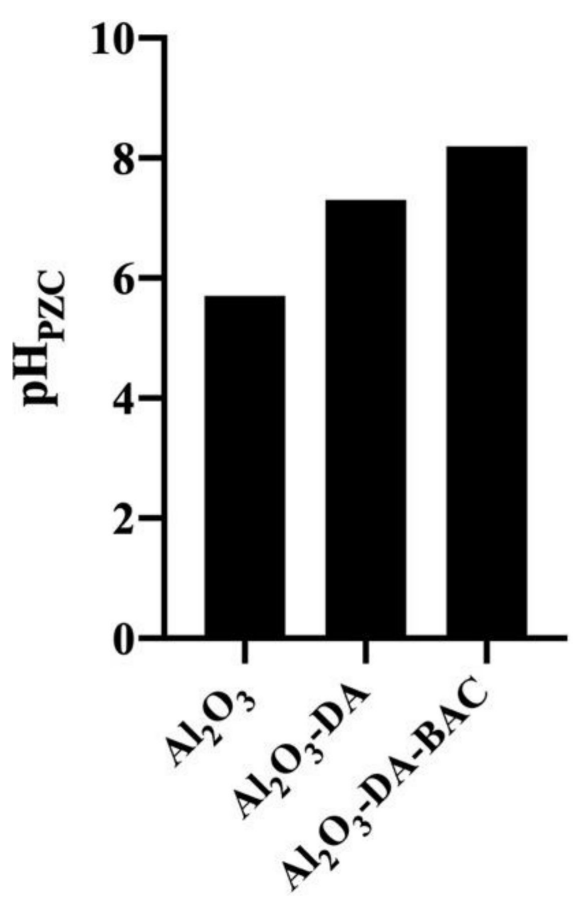

Figure 4. Point of zero charge of the functionalized and $\mathrm{Al}_{2} \mathrm{O}_{3}$ particles.

Furthermore, after BAC incorporation, the $\mathrm{pH}_{\mathrm{PZC}}$ raised to 8.2. The basic nature of benzalkonium chloride corroborates the $\mathrm{pH}_{\mathrm{PZC}}$ increase.

\subsubsection{Fourier-Transform Infrared Spectroscopy (FTIR) Analysis}

FTIR spectra of $\mathrm{Al}_{2} \mathrm{O}_{3}$ particles (Figure 5) show a band in the region of 3300-3700 $\mathrm{cm}^{-1}$, which corresponds to the water O-H stretch [33]. Ribena [34] also found bands in the region 3000-3400 $\mathrm{cm}^{-1}$ after coating the surface of its particles with dopamine and attributed it to the intermolecular hydrogen bonds $(\mathrm{O}-\mathrm{H}, \mathrm{N}-\mathrm{H}$ and aromatic $\mathrm{CH} 2$ stretching vibrations) naturally occurring between dopamine molecules. Regarding Figure 5, another band was found in the region of $1580-1650 \mathrm{~cm}^{-1}$ for $\mathrm{Al}_{2} \mathrm{O}_{3}-\mathrm{DA}$ and $\mathrm{Al}_{2} \mathrm{O}_{3}-\mathrm{DA}-\mathrm{BAC}$ particles. This band corresponds to N-H bending [33], meaning that functionalization with dopamine coated the particles with amine groups. The functionalization of particles with BAC resulted in the appearance of two small peaks at 1153 and $1211 \mathrm{~cm}^{-1}$ on the curve in red. These peaks are associated to $\mathrm{C}-\mathrm{N}$ and $\mathrm{N}-\mathrm{CH}_{3}$ stretching vibrations, which are characteristic of quaternary amines $[35,36]$.

FTIR results proved again the successful functionalization of particles with nitrogen and biocidal groups.

The overall physical and chemical characterizations discussed above (BAC peaks in the FTIR diagram, mass loss in the TG curves, XRD analysis and the sorption isotherms) point-out to a successful immobilization of active BAC groups after the proposed functionalization. 


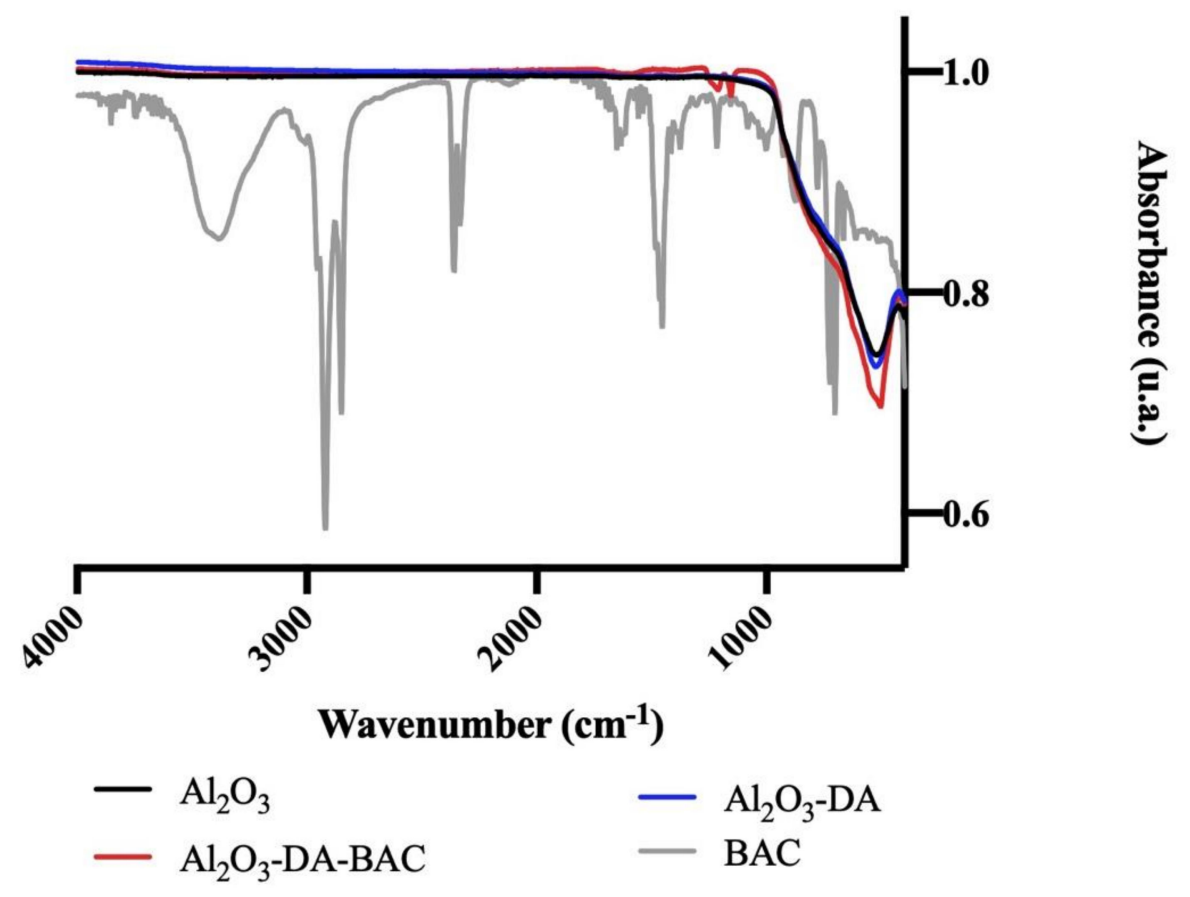

Figure 5. Fourier-Transform Infrared Spectroscopy (FTIR) spectra of functionalized and $\mathrm{Al}_{2} \mathrm{O}_{3}$ particles. Benzalkonium chloride (BAC) in solution was used as control.

\subsection{Particles' Antimicrobial Activity}

To assess the Escherichia coli susceptibility to the immobilized biocide, zones of inhibition were determined. Data shown in Table 2 demonstrate that $\mathrm{Al}_{2} \mathrm{O}_{3}$ and $\mathrm{Al}_{2} \mathrm{O}_{3}$-DA particles do not induce any zone of inhibition, suggesting that the core materials without biocide, for the present test conditions, have a very small or no antibacterial effect on $E$. coli. On the other hand, $\mathrm{Al}_{2} \mathrm{O}_{3}$-DA-BAC particles exhibited a zone of inhibition diameter of $18 \pm 2 \mathrm{~mm}$, which implies that there is some biocide leaching from the particles. Hassan and Elbagoury [37], while studying the susceptibility of some bacterial isolates to BAC in solution, observed similar inhibition diameters. These authors found zone of inhibition average diameters of 13 and $17 \mathrm{~mm}$ when Pseudomonas spp. cells were exposed to a $\%$ BAC solution.

Table 2. Zone of inhibition diameter obtained for the tested particles against Escherichia coli.

\begin{tabular}{cc}
\hline & Zone of Inhibition (mm) \\
\hline $\mathrm{Al}_{2} \mathrm{O}_{3}$ & $0 \pm 0$ \\
\hline $\mathrm{Al}_{2} \mathrm{O}_{3}$-DA & $0 \pm 0$ \\
\hline $\mathrm{Al}_{2} \mathrm{O}_{3}$-DA-BAC & $18 \pm 2$ \\
\hline
\end{tabular}

Values are presented as the mean \pm standard deviation of two independent experiments.

The formation of a zone of inhibition is related to the diffusion constant of the antimicrobial agent [38-40] and, therefore, can be related to its amount and motility. According to the same authors [38-40], a zone of inhibition appears when the concentration of an antimicrobial agent exceeds the minimum inhibitory concentration or its critical concentration [38-41]. Although, this test highly depends on several experimental factors (e.g., test medium, organism and its microbial concentration and biocide type), it is expected that for the same experimental conditions, zones of inhibition can provide a qualitative indication of the bacterial susceptibility against a given antimicrobial agent [42]. Therefore, the results in Table 2 suggest that the functionalized particles $\left(\mathrm{Al}_{2} \mathrm{O}_{3}\right.$-DA-BAC) have a strong antibacterial activity potential. 


\subsection{Effect of Immobilized Biocide Concentration on the Particles' Antimicrobial Activity}

According to what was described in the Materials and Methods section, different ratios of particles per unit volume of solution, summarized in Table 3, were tested. It is important to note that the concentration of immobilized biocide per unit mass of each particle was $3 \%(w / w)$ of $\mathrm{BAC}$, according to the data obtained in the thermogravimetric analysis (as described in Section 2.1.1). Therefore, the tested concentrations of 500, 1000 and $3000 \mathrm{mg} / \mathrm{L}$ refer to the "overall concentration of immobilized biocide" defined as mg of immobilized biocide per $\mathrm{L}$ of total liquid volume (bacterial suspension). Thus, the different concentrations correspond to different amounts of particles per unit liquid volume.

Table 3. Tested conditions regarding the overall immobilized biocide concentration.

\begin{tabular}{cccc}
\hline \multirow{2}{*}{ Particles } & $\begin{array}{c}\text { Immobilized BAC } w / w \text { (\%): Mass } \\
\text { of BAC }(\mathbf{g}) \text { per } \mathbf{1 0 0} \mathbf{g} \text { of Particles }\end{array}$ & $\begin{array}{c}\text { Ratio Mass of Particles } \\
(\mathbf{g}) / \text { Volume of Solution }(\mathbf{L})\end{array}$ & $\begin{array}{c}\text { Overall Concentration under Test (mg } \\
\text { of Immobilized Biocide/L Solution) }\end{array}$ \\
\hline \multirow{2}{*}{$\mathrm{Al}_{2} \mathrm{O}_{3}$-DA-BAC } & 3 & 16.8 & 500 \\
& & 33.5 & 1000 \\
\cline { 3 - 4 } & & 100.3 & 3000 \\
\hline
\end{tabular}

The antimicrobial effect of such functionalized particles $\left(\mathrm{Al}_{2} \mathrm{O}_{3}-\mathrm{DA}-\mathrm{BAC}\right)$, considering the different overall concentrations of immobilized biocide, was evaluated according to the bacteria culturability and membrane integrity (propidium iodide, PI, uptake percentage) criteria.

\subsubsection{Culturability}

The reduction of the colony forming units per milliliter $(\mathrm{CFU} / \mathrm{mL})$ of $E$. coli planktonic cells over time, exposed to different overall concentrations of $\mathrm{Al}_{2} \mathrm{O}_{3}$-DA-BAC particles, is shown in Figure 6a. In this figure, it can be seen that higher concentrations of overall immobilized biocide require less contact time to completely inactivate bacterial cells. For instance, a statistically significant $(p<0.05)$ six-log reduction (until no CFU count) was observed after a five-min contact time when using the overall biocide concentration of $3000 \mathrm{mg} / \mathrm{L}$. The contact time required to obtain no CFU count was respectively $15 \mathrm{~min}$ and $30 \mathrm{~min}$ for $1000 \mathrm{mg} / \mathrm{L}$ and $500 \mathrm{mg} / \mathrm{L}$ immobilized biocide concentrations.

Furthermore, Figure 6a shows that the control particles $\left(\mathrm{Al}_{2} \mathrm{O}_{3}-\mathrm{DA}\right)$ had no impact on the culturability, since no decrease on $\mathrm{CFU} / \mathrm{mL}$ was observed. Statistically significant differences $(p<0.05)$ were found between the biocidal particles (at all the tested concentrations) and the control particles, confirming the effective bactericidal activity of the BAC-loaded particles and the non-existing antimicrobial activity of the core-base materials. Although some studies report the antimicrobial activity of dopamine, such antimicrobial activity seemed to be related with the high concentration of DA tested. For example, Zhao et al. [43] reported that at $100 \mathrm{mg} / \mathrm{mL}$ of DA coating had an antimicrobial effect against $E$. coli cells, while at 30 times lower concentrations, Iqbal et al. [44] found that DA did not exhibit any antimicrobial activity against the same bacterium. Indeed, the concentration in the $\mathrm{Al}_{2} \mathrm{O}_{3}$ DA particles in this study is only $2 \mathrm{mg} / \mathrm{mL}$ of DA, which agrees with the idea that low concentrations of DA do not have an antimicrobial effect. 


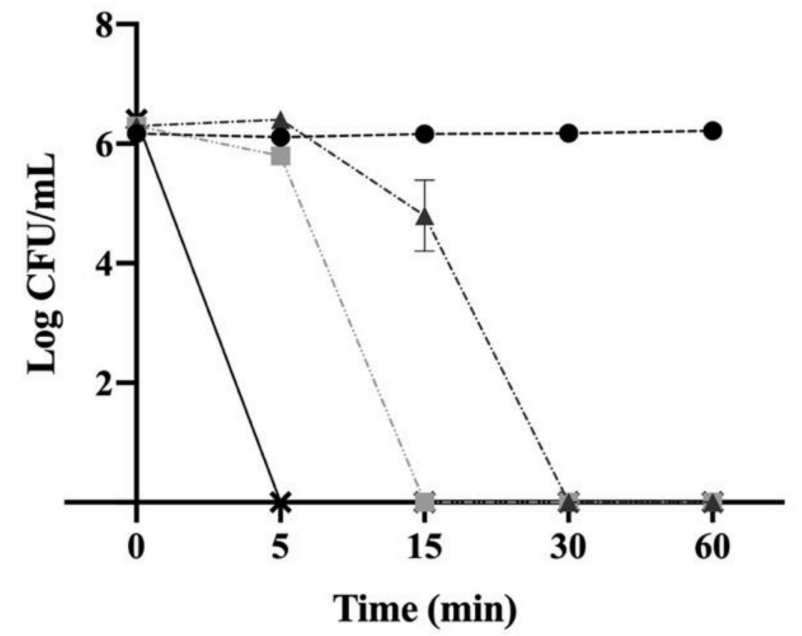
$\mathrm{Al}_{2} \mathrm{O}_{3}-\mathrm{DA}$
- - $\mathrm{Al}_{2} \mathrm{O}_{3}$-DA-BAC $500 \mathrm{mg} / \mathrm{L}$
$\mathrm{Al}_{2} \mathrm{O}_{3}$-DA-BAC $1000 \mathrm{mg} / \mathrm{L} \quad * \quad \mathrm{Al}_{2} \mathrm{O}_{3}$-DA-BAC $3000 \mathrm{mg} / \mathrm{L}$

(a)

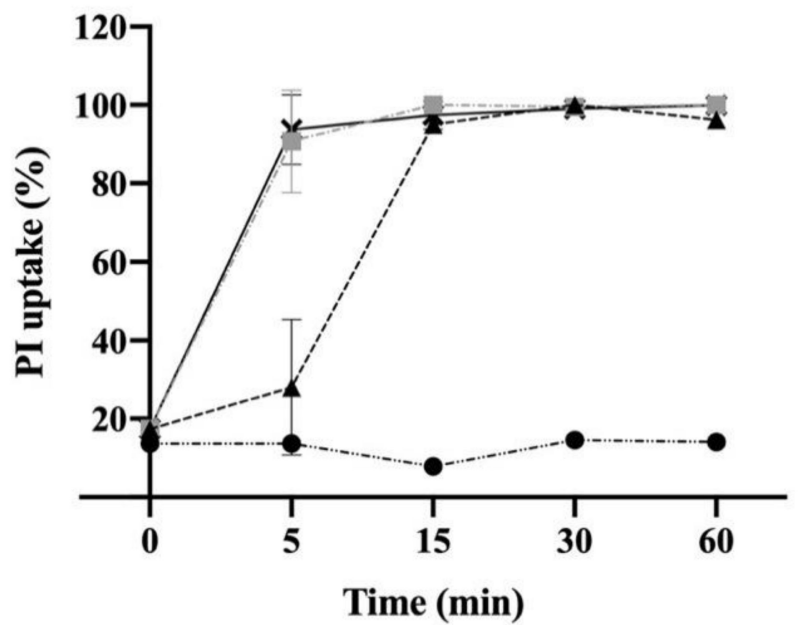

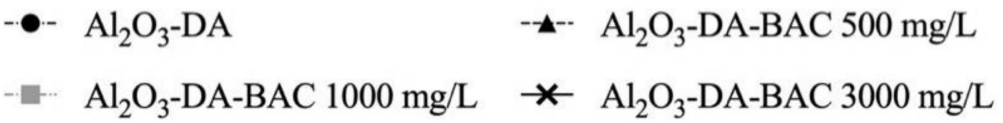

(b)

Figure 6. Logarithm of the colony forming units per milliliter (CFU/mL) (a) and propidium iodide (PI) uptake (\%) (b) of Escherichia coli planktonic cells exposed to dopamine (DA)-functionalized particles over time during the first use. The overall tested concentrations were: 500, 1000 and $3000 \mathrm{mg} / \mathrm{L}$. of $\mathrm{Al}_{2} \mathrm{O}_{3}$, and $\mathrm{Al}_{2} \mathrm{O}_{3}$-DA particles were used as controls. Error bars correspond to the standard deviation of the mean determined for two independent experiments.

\subsubsection{Membrane Integrity}

The effect of the functionalized particles over time on the membrane integrity (represented in terms of PI uptake \%) of the bacterial cells was also studied for different biocide concentrations- see Figure $6 \mathrm{~b}$. As expected, the impact of the control particles $\left(\mathrm{Al}_{2} \mathrm{O}_{3}-\mathrm{DA}\right.$, before functionalization), on membrane integrity loss was negligible when compared to the particles containing the immobilized biocide $(p<0.05)$. 
The results show that total loss of membrane integrity (100\% PI uptake) was achieved with functionalized $\mathrm{Al}_{2} \mathrm{O}_{3}$-DA-BAC particles for all tested concentrations, although the lower biocide concentration $(500 \mathrm{mg} / \mathrm{L})$ took some more time to reach very high levels (above $90 \%$ ) of cell membrane permeabilization. It could be said that increasing the overall immobilized biocide concentration decreases the contact time needed to fully permeabilize bacterial membrane and reduce culturability. This is in accordance to what is widely described in the literature concerning the concentration and contact time of free biocides $[45,46]$. Additionally, Pazos-Ortiz et al. [47] found that bacterial inhibition was dose-dependent, when studying the antimicrobial activity of silver nanoparticles. However, the results obtained in the present work, concerning a liquid biocide incorporated in inert particles (similar curves for 1000 and $3000 \mathrm{mg} / \mathrm{L}$, with faster effects than for the lower concentration of $500 \mathrm{mg} / \mathrm{L}$ ) leave some doubt about the possible existence of a critical concentration above which the biocide concentrations remain equally efficient.

The conclusions are also not so straightforward when comparing culturability and membrane permeabilization. Looking at Figure $6 a, b$, a similar level of membrane permeabilization is observed at five min for concentrations of $3000 \mathrm{mg} / \mathrm{L}$ and $1000 \mathrm{mg} / \mathrm{L}$, but the CFU log reduction is much more pronounced for the higher concentration than for $1000 \mathrm{mg} / \mathrm{L}$. These discrepancies suggest that the membrane damage caused by the antimicrobial agent was not enough to affect the bacterial growth on solid media, depending on the biocide concentration.

There are several studies in the literature reporting differences between these two methods, mostly related to the existence of more viable than culturable cells. One of such examples is the work of Ferreira, et al. [48], who observed that some cells with intact membranes (no PI uptake) were not culturable-the so called "viable but nonculturable" state. Nonetheless, it has also been reported by Rosenberg et al. [49] that PI-based viability tests can overestimate the number of dead cells, since they found that a dual-species 24-h biofilm presented $96 \%$ of PI-positive cells, although $68 \%$ of those cells were still metabolically active, and more than $80 \%$ of these cells were cultivable after harvesting. Furthermore, it has been shown that membranes from cells exposed to stress conditions (starvation, heat, biocide, etc.), tend to become more permeable to PI, resulting in mistakenly marking viable cells as dead [50-52]. Interestingly, it was also found that if such cells were re-incubated for a certain period after being exposed to the stress conditions, they could recover and repair the membrane damage [50].

The results discussed herein suggest that membrane integrity assays do not correlate with the ability of bacteria to grow on solid medium. Therefore, they confirm the importance of complementing the "viability" assays methods with a cultivation method [53] or to incubate the cells prior to the membrane integrity staining procedure [50].

\subsection{Effect of Particle Reuse on Their Antimicrobial Activity}

After being used once (first use), the same particles were reused and their antimicrobial activity regarding culturability (Figure 7a) and PI uptake (Figure 7b) was re-evaluated. In general, the particles lost some performance upon reuse, i.e., reusing the particles at 3000 and $1000 \mathrm{mg} / \mathrm{L}$ required more time to reach the maximum efficiency in terms of CFU count and \% of PI uptake. This issue is addressed in Section 2.5, where the mechanisms of particles' antimicrobial activity are discussed. 

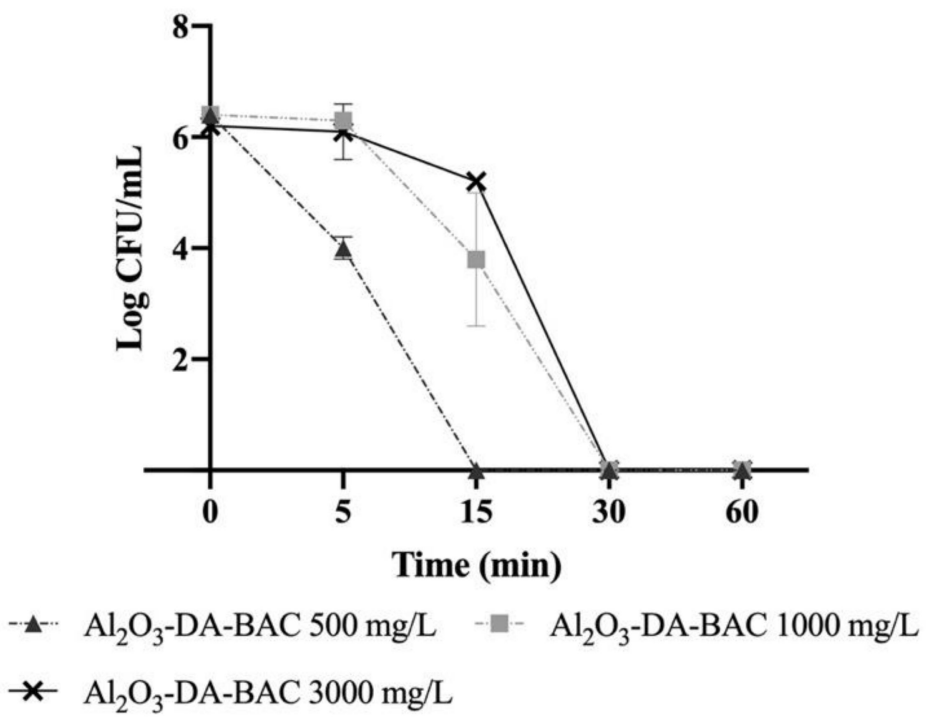

(a)

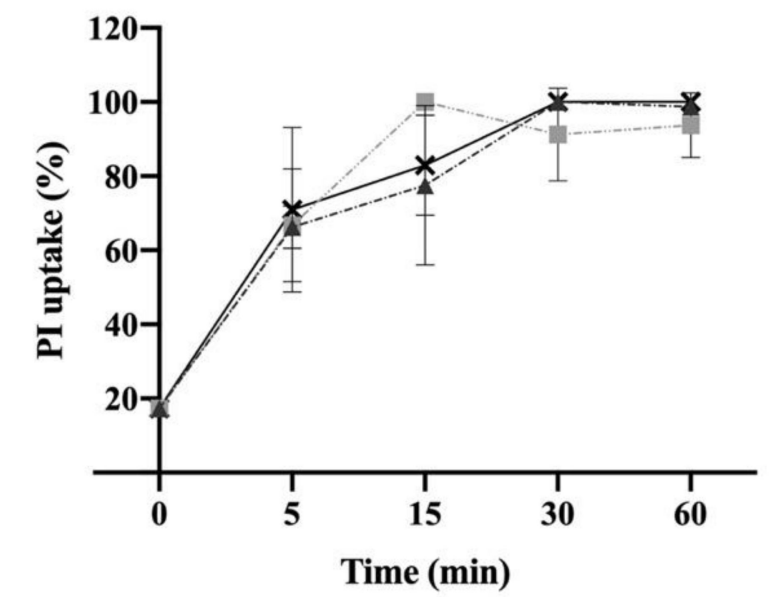

\footnotetext{
- $\mathrm{Al}_{2} \mathrm{O}_{3}$-DA-BAC $500 \mathrm{mg} / \mathrm{L}$ - $\mathrm{Al}_{2} \mathrm{O}_{3}$-DA-BAC $1000 \mathrm{mg} / \mathrm{L}$

$* \mathrm{Al}_{2} \mathrm{O}_{3}$-DA-BAC $3000 \mathrm{mg} / \mathrm{L}$
}

(b)

Figure 7. Logarithm of the colony forming units per milliliter (CFU/mL) (a) and propidium iodide (PI) uptake (\%) (b) of Escherichia coli planktonic cells exposed to functionalized particles over time after reuse. The overall tested concentrations were: 500, 1000 and $3000 \mathrm{mg} / \mathrm{L}$. Error bars correspond to the standard deviation of the mean determined for two independent experiments.

However, there is a specific case that stands out: $\mathrm{Al}_{2} \mathrm{O}_{3}-\mathrm{DA}-\mathrm{BAC}$ at $500 \mathrm{mg} / \mathrm{L}$. In this case, at first sight there would be an improvement of the particles' performance on reuse, since the contact time until total inactivation seems to decrease from $30 \mathrm{~min}$ on the first use to $15 \mathrm{~min}$ upon reuse. This can be related to the large period between sampling time points. Most probably, the total inactivation might occur at min 16 or 17 . This would not be detected in the present tests, but the actual performance of the $\mathrm{Al}_{2} \mathrm{O}_{3}$-DA-BAC at 500 $\mathrm{mg} / \mathrm{L}$ would be the same in the first use and in reuse.

Similar to what was observed in the first use, the PI uptake percentages (Figure 7b) do not match with the CFU results (Figure 7a). For example, regarding $\mathrm{Al}_{2} \mathrm{O}_{3}$-DA-BAC at $500 \mathrm{mg} / \mathrm{L}$, although the cells lost their culturability at $15 \mathrm{~min}, 22 \%$ of them did not present 
damaged membranes. Possibly, this may be related to the fact that the cells have reached the "viable but non-culturable" state [49].

Due to the differences observed after reuse, a TG analysis of the particles after being reused was performed (see Figure 8). It is important to refer that the samples used were particles from the 3000-mg/L experiments.

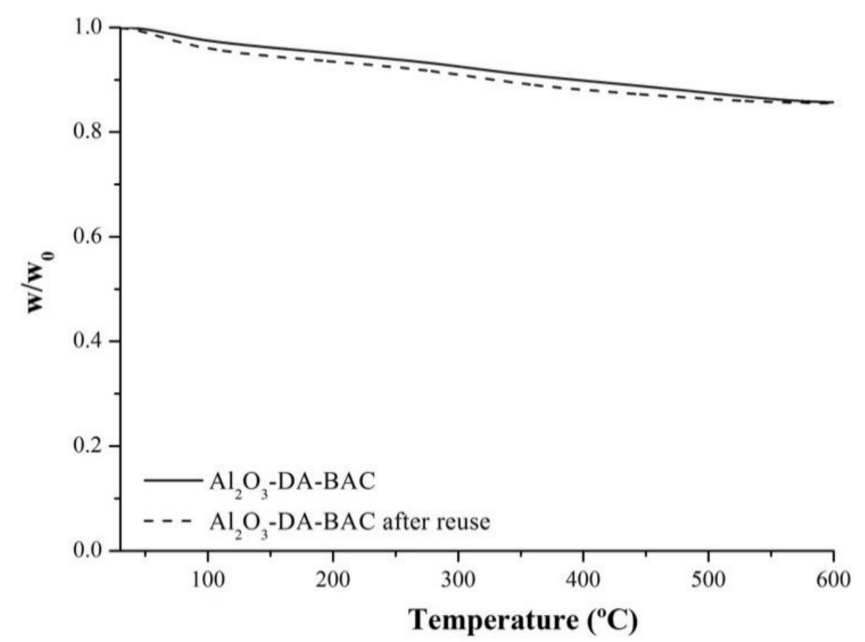

Figure 8. Thermogravimetric analysis (TG) of $\mathrm{Al}_{2} \mathrm{O}_{3}$-DA-BAC particles before the antimicrobial experiments and after being reused.

From Figure 8, it is possible to see that the curves are very similar. The amount of BAC in the samples after use is still in the order of $3 \%(w / w)$, meaning that there was no significant release of BAC. The results from the zone of inhibition seem to indicate a higher release, but it is known that the biocide/antibiotic concentrations in agar are higher than in liquid medium, causing higher death rates [54]. The zone of inhibition is only a qualitative method, while TG gives quantitative results. Furthermore, in the inhibition zone experiments the particles are in contact with bacteria for $24 \mathrm{~h}$, which is much longer than the contact time of the killing experiments (one hour). Gathering all data, it is possible to conclude that there is a small and slow release of biocide from the particles.

\subsection{Hypothesis for the Underlying Mechanism of Action of Immobilized Biocide}

The results observed after reuse can be related to the following main question: "what are the mechanisms of antimicrobial action of biocide-loaded particles?" There are some hypotheses, namely: (i) bacteria are inactivated by the free biocide resulting from the slow release to the bulk solution, (ii) direct contact with the immobilized biocide (also known as "contact killing") is responsible for the antimicrobial action and (iii) there is a combination of both mechanisms of action stated above.

If the first hypothesis was behind the antimicrobial action of the particles, the reuse should have a similar behavior. Since the amount of biocide immobilized per unit mass of particle is very high, it would be expected that upon reuse there would still remain a considerable amount of biocide to be released. Additionally, the hypothesis that all or most of the immobilized biocide could be released during the first use is not plausible, otherwise the killing kinetics for the 3000 and $1000 \mathrm{mg} / \mathrm{L}$ concentrations would be faster.

The second hypothesis is that bacteria can be killed by contact with the BAC molecules immobilized onto the particles surface [54,55]. Several authors have been developing contact-active materials, which consist of coating a surface with a biocidal layer [56-58]. Synthetic QACs are by far the most used molecules for this purpose [59]. The mechanism of antimicrobial action of QACs seems to be due to electrostatic interactions between the positively charged QAC molecules and the negatively charged phospholipids present in the cytoplasmatic membrane of bacteria. Furthermore, the hydrophobic alkyl chain of QACs punches the membrane, leading to membrane disruption, cellular content leakage 
and microbial death [59-61]. Moreover, for the interaction between BAC molecules and bacteria to occur, the particles need to be in close contact with bacteria. Of course, the BAC molecules inside the pores will not be readily available for bacteria [62], since the particles are mesoporous (pore diameters between 2 and $50 \mathrm{~nm}$ [63]) and bacteria (due to their bigger size) cannot enter the pores. In the work of He et al. [56], they found that bacteria are dead upon contact with the immobilized QACs. However, it is known that these antimicrobial moieties can be blocked by dead adherent bacteria [56,64]. This mechanism of contact killing and consequent biocide blocking by dead bacteria may apply to the results observed in our study. Attraction between the particles, which display positive surface charge at $\mathrm{pH}$ around 7 (because the isoelectric point is $\mathrm{pH}=8.2$; see Figure 4), and the negatively charged bacterial surfaces is most probable to occur. It is therefore plausible that some dead bacteria from the $1^{\text {st }}$ use remained attached to the particles' surface, which would explain the performance decrease upon reuse.

The third hypothesis assumes that the mechanism of action is a combination of the first and the second hypotheses. In fact, as it was already discussed, the first theory alone is not plausible, but the results from the zone of inhibition show some biocide leaching, which cannot be neglected and could contribute to some (although low) antimicrobial action of the biocide in solution.

Work is now being carried out in order to fully understand these interactions between functionalized particles and bacteria. The implementation of additional analytical methodologies to deeply characterize the mechanism of action of the immobilized BAC and compare it with the mechanism of free biocide seems also to be a key step for further understanding of the results. Finally, assuming that particles lose some of their performance, several cycles of reuse assays should be performed in order to characterize their lifetime effectiveness. If so, for real-field applications, a particle regeneration (cleaning) step would be periodically needed, implying the simultaneous operation of two or more alternating parallel particle bed systems.

\section{Materials and Methods}

3.1. Reagents

Dopamine (3-Hydroxytyramine Hydrochloride) was obtained from Tokyo Chemical Industry Co., Ltd. (Tokyo, Japan). Benzalkonium chloride $\geq 95$ was obtained from SigmaAldrich (Steinheim, Germany). Tris base was obtained from ChemCruz ${ }^{\mathrm{TM}}$ Biochemicals (Dallas, Tx, USA).

\subsection{Preparation and Functionalization of Particles}

Alumina oxide pellets $\left(\mathrm{Al}_{2} \mathrm{O}_{3}\right.$, Saint-Gobain, Stow, MA, USA) with approximately 3 $\mathrm{mm}$ were selected as start material. Pellets activation was accomplished in a heat treatment at $600{ }^{\circ} \mathrm{C}$ under air atmosphere for $6 \mathrm{~h}$.

\subsubsection{Initial Functionalization of Alumina Oxide Particles with DA}

In this work, an amino-functionalization strategy was tested using dopamine (DA) as intermediate for BAC immobilization.

Dopamine hydrochloride $(2 \mathrm{mg} / \mathrm{mL})$ was dissolved in Tris buffer solution $(\mathrm{pH}=8.5$, $50 \mathrm{mM}$ ). The particles $(5 \mathrm{~g})$ were placed in contact with $50 \mathrm{~mL}$ of dopamine solution and left in agitation for $24 \mathrm{~h}$. These $\mathrm{Al}_{2} \mathrm{O}_{3}$-DA particles were washed with distilled water to neutral $\mathrm{pH}$, dried for $24 \mathrm{~h}$ in the oven at $120^{\circ} \mathrm{C}$ and stored in a desiccator.

\subsubsection{Immobilization of Biocide on the Surface of Alumina Oxide Particles}

Samples of $\mathrm{Al}_{2} \mathrm{O}_{3}$-DA particles $(2 \mathrm{~g})$ were added to $100 \mathrm{~mL}$ of $5 \%(w / v)$ QAC solution and allowed to interact for $72 \mathrm{~h}$ at room temperature and with agitation speed of $140 \mathrm{rpm}$. The resulting particles $\left(\mathrm{Al}_{2} \mathrm{O}_{3}\right.$-DA-BAC) were washed with distilled water to neutral $\mathrm{pH}$, dried for $24 \mathrm{~h}$ in the oven at $80^{\circ} \mathrm{C}$ and stored in a desiccator. 


\subsection{Particles Characterization}

\subsubsection{Thermal Stability of the Particles}

Thermogravimetric analyses (TG) were performed to determine the particles content in terms of functional groups, after each immobilization step. It has been performed on a Mettler-Toledo TGA/DSC 1 STAR system. The thermal stability of samples was evaluated by heating the different samples up to $600{ }^{\circ} \mathrm{C}$ at $3{ }^{\circ} \mathrm{C} / \mathrm{min}$ under air atmosphere and monitoring their weight loss.

\subsubsection{Textural Characterization of the Particles}

The textural characterization of the materials was based on the $\mathrm{N}_{2}$ physisorption adsorption-desorption isotherms, determined at $-196^{\circ} \mathrm{C}$ with Quantachrome Autosorb IQ2. The surface area $\left(S_{\mathrm{BET}}\right)$ was calculated from nitrogen adsorption isotherms using the Brunauer, Emmet, and Teller (BET) equation [65]. Pore size distributions were obtained from the desorption branch of the isotherm using the Barrett, Joyner and Halenda (BJH) method [66].

\subsubsection{Structural Properties of the Particles}

Phase composition of the samples was analyzed by means of powder X-ray diffraction using a PanAnalytical X Pert PRO diffractometer set at $45 \mathrm{kV}$ and $40 \mathrm{~mA}$, using $\mathrm{Cu} \mathrm{K} \alpha$ radiation $(\lambda=1.541874 \AA)$ and a PIXcel detector. Data were collected using Bragg-Brentano configuration in the $2 \theta$ range of 20 to $80^{\circ}$ with a scan speed of $0.01^{\circ} / \mathrm{s}$

\subsubsection{Determination of Particle Surface Charge}

The Zeta potential measurements were carried out using Dynamic Light Scattering by a Nano Particle Analyzer SZ-100 (Horiba Scientific, Longjumeau cedex, France). The particles (in powder) were placed in ultrapure water and the $\mathrm{pH}$ was adjusted from 2 to 11 by using an appropriate amount of $0.1-\mathrm{M} \mathrm{NaOH}$ or $0.1-\mathrm{M} \mathrm{HCl}$. After being sonicated for 30 $\mathrm{min}$, the particles surface charge was determined. At least 5 measurements were performed for each sample and the measurements repeated in two different occasions.

\subsubsection{Fourier-Transform Infrared Spectroscopy (FTIR)}

Spectroscopic measurements were performed with a Vertex 80v FTIR spectrometer (Bruker Optics) using Attenuated total reflectance (ATR) mode. The samples between 400 and $4000 \mathrm{~cm}^{-1}$ were analyzed with 64 scans averaging $4 \mathrm{~cm}^{-1}$ and two independent experiments were performed for each sample.

\subsection{Particles Antimicrobial Activity}

\subsubsection{Microorganism}

Bacterial suspensions of Escherichia coli CECT 434 were obtained from an overnight growth at $37^{\circ} \mathrm{C}$ and under agitation $(120 \mathrm{rpm})$ in R2A broth medium with the following composition (per liter): 0.5 g glucose (CHEM-LAB, Zedelgem, Belgium), 0.5 g peptone (Oxoid, Hampshire, England, UK), $0.1 \mathrm{~g} \mathrm{MgSO}_{4} .7 \mathrm{H}_{2} \mathrm{O}$ (Merck, Darmstadt, Germany), 0.5 g casein hydrolysate (Oxoid, Hampshire, England, UK), 0.3 g sodium pyruvate (Fluka, Steinheim, Germany), $0.5 \mathrm{~g}$ starch (Sigma-Aldrich, Steinheim, Germany ), $0.5 \mathrm{~g}$ yeast extract (Merck, Darmstadt, Germany) and $0.4 \mathrm{~g} \mathrm{~K}_{2} \mathrm{HO}_{4} \mathrm{P} \cdot 3 \mathrm{H}_{2} \mathrm{O}$ (Applichem Panreac, Darmstadt, Germany).

\subsubsection{Antimicrobial Activity of the Particles against E. coli}

The antimicrobial activity of the particles was tested against $E$. coli by using the KirbyBauer disk diffusion assay. The overnight culture was diluted to achieve $10^{6} \mathrm{CFU} / \mathrm{mL}$. Then, $100 \mu \mathrm{L}$ of the test suspension was swabbed on Plate Count Agar (PCA) plates. Afterwards, the particles were placed on the center of the inoculated agar plates. Antibacterial activity was assessed by measuring the diameter of the inhibition zone ( $\mathrm{mm})$-a circular area 
around the particle where bacteria has not grown—on the surface of the plates. Two independent experiments with triplicates were performed for each case.

3.4.3. Effect of Particle Functionalization and Biocide Concentration on Antimicrobial Activity

The antimicrobial activity of the biocidal particles was tested against E. coli. An overnight culture was centrifuged at $4000 \mathrm{rpm}$ for $12 \mathrm{~min}$. The pellets were resuspended in phosphate buffered saline (PBS) buffer solution, washed twice and resuspended in the same solution. The bacterial count was then adjusted to $10^{6} \mathrm{CFU} / \mathrm{mL}$. The particles were incubated with the bacterial cells for 5, 15, 30 and $60 \mathrm{~min}$. As stated in the Introduction section, the aim of this work is to gather critical information on the properties and performance of the biocidal particles to proceed with the design of an antimicrobial particle bed-reactor. Therefore, by varying the number of particles, three different ratios of mass of particles per volume of solution were tested, corresponding to the following overall immobilized biocide concentrations (mass of immobilized biocide per total volume of solution): $500 \mathrm{mg} / \mathrm{L}, 1000 \mathrm{mg} / \mathrm{L}$ and $3000 \mathrm{mg} / \mathrm{L}$ (Table 3). These ratios were established attending to the bed-reactor dimensions, the particles characteristics (dimensions and density) and considering the wall effect approach [12]. The overall tested concentrations also considered the volume of solution (which was kept the same in all assays: $25 \mathrm{~mL}$ ) and the amount of immobilized BAC per unit mass of particles (3\%). The amount of biocide incorporated onto the particles' surface was determined by TG, by calculating the mass loss that occurred at the BAC decomposition temperature range.

The biocidal activity was evaluated in terms of culturability and membrane integrity due to propidium iodide (PI) uptake. After being exposed to the particles, the bacterial suspension was successively diluted in PBS and culturability was assessed on Plate Count Agar (PCA) plates using the drop plate method [67]. Thereafter, plates were incubated at $37^{\circ} \mathrm{C}$ for $24 \mathrm{~h}$ and the colonies enumerated. The culturability results are expressed as logarithm of the Colony Forming Units per milliliter (CFU/mL), with bacterial detection limit being $10^{2} \mathrm{CFU} / \mathrm{mL}(2 \mathrm{log})$. For membrane integrity assessment, the LIVE/DEAD ${ }^{\circledR}$ Baclight $^{\mathrm{TM}}$ kit (Invitrogen) was used. This kit is composed by two nucleic acids stains: SYTO9 ${ }^{\mathrm{TM}}$ and PI. The last compound only penetrates into cells with damaged membranes, staining them in red. SYTO9 ${ }^{\mathrm{TM}}$ crosses all bacterial membranes, staining the cells with green color [48,68]. To implement the method, cells were diluted 1:10 in PBS and $1 \mathrm{~mL}$ aliquot was filtered on a $0.2-\mu \mathrm{m}$ Nucleopore ${ }^{\circledR}$ (Whatman) black polycarbonate membrane and stained with $250 \mu \mathrm{L}$ of SYTO9 ${ }^{\mathrm{TM}}$ and $250 \mu \mathrm{L}$ of PI. The stain reagents reacted for $7 \mathrm{~min}$ in the dark at room temperature. After that, the excess reagents were filtered, and the membrane mounted on a slide with BacLight mounting oil. The microscope, software, and the emission and excitation filters used were the same as described by Ferreira et al. [48]. The results were represented in terms of PI uptake percentage. Two independent experiments were performed for each case.

\subsubsection{Effect of Reuse on Particles' Antimicrobial Activity}

After the first use (1st use), the functionalized particles were washed with $1 \mathrm{~L}$ of distilled water and dried at $120^{\circ} \mathrm{C}$ for $24 \mathrm{~h}$. Then, the particles were reused once, and their antimicrobial activity was re-evaluated as described in Section 3.4.3. Hereafter, this second use of the particles will be named-reuse.

\subsection{Statistical Analysis}

Data obtained for culturability and membrane integrity were analyzed using the statistical software GraphPad Prism 8.0 (GraphPad Software, Inc., San Diego, California USA). The influence of biocide concentration and reuse were evaluated using a two-way ANOVA with Tukey's multiple comparison test. Differences were considered relevant if $p<0.05$. All the statistical analyses were performed using the GraphPad Prism 8 software (GraphPad Software, Suite, San Diego, California, USA). 


\section{Conclusions}

Alumina oxide particles were successfully functionalized with the antimicrobial agent benzalkonium chloride (BAC). To the best of our knowledge, this was the first work that accomplished the immobilization of biocides on the surface of macroscopic metal oxide particles, using DA (dopamine) as a precursor for biocide fixation. The functionalized particles $\left(\mathrm{Al}_{2} \mathrm{O}_{3}\right.$-DA-BAC) showed a consistent antimicrobial effect against $E$. coli, which increased with the overall immobilized biocide concentration. In general, there was some decrease in the particles' performance on reuse, corresponding to an increase in the contact time required to reach similar results to the $1^{\text {st }}$ use (for the same conditions). Even so, a high antimicrobial activity was still achieved upon reuse, indicating the feasibility of the $\mathrm{Al}_{2} \mathrm{O}_{3}$ DA-BAC particles for water disinfection, as a final polishing step before Reverse Osmosis treatment. The total cost of the core particles and the functionalization methods here described is relatively low when compared to the cost of, for example, silver nanoparticles used in lab scale experiments and are expected to be substantially reduced when going to an industrial scale production. In order to optimize the performance of the functionalized particles, the mechanism of action of the immobilized biocide needs to be studied in detail to understand how the immobilized biocide interacts with bacteria, in comparison with the free biocide mechanisms. Additionally, the possible interactions between functionalized particles and dead bacteria (or dead cell components) should be further investigated and characterized.

Author Contributions: Formal analysis, A.C.B., A.P. and L.F.M.; methodology, A.C.B. and J.P.S.S.; supervision, A.P., L.F.M. and J.P.S.S.; writing-original draft, A.C.B. and A.P. and writing-review and editing, A.C.B., A.P., L.F.M. and J.P.S.S. All authors have read and agreed to the published version of the manuscript.

Funding: This work was financially supported by: (i) Base Funding-UIDB/00511/2020 of the Laboratory for Process Engineering, Environment, Biotechnology and Energy — LEPABE—funded by national funds through the FCT /MCTES (PIDDAC); (ii) Project INN-INDIGO/0001/2014- POMACEAAffordable technology for mitigation of membrane (bio) fouling through oPtimizatiOn of pretreatMent And ClEAIng methods, funded by the ERA-NET-European Research Area Networks program through the FCT, by national funds.; and (iii) Project pBio4.0-Preventing Biofouling in Membrane Systems, with the reference POCI-01-0247-FEDER-033298, co-funded by the European Regional Development Fund (ERDF), through the Operational Programme for Competitiveness and Internationalization (COMPETE 2020), under the PORTUGAL 2020 Partnership Agreement. A.C.B acknowledges the receipt of a Ph.D. grant from FCT (SFRH/BD/146028/2019).

Institutional Review Board Statement: Not applicable.

Informed Consent Statement: Not applicable.

Data Availability Statement: Not applicable.

Conflicts of Interest: The authors declare no conflict of interest.

\section{References}

1. Boretti, A.; Rosa, L. Reassessing the projections of the World Water Development Report. npj Clean Water 2019, 2, 1-6. [CrossRef]

2. Vrouwenvelder, J.; Van der Kooij, D. Diagnosis, prediction and prevention of biofouling of NF and RO membranes. Desalination 2001, 139, 65-71. [CrossRef]

3. Majamaa, K.; Johnson, J.E.; Bertheas, U. Three steps to control biofouling in reverse osmosis systems. Desalination Water Treat. 2012, 42, 107-116. [CrossRef]

4. Vrouwenvelder, J.; Beyer, F.; Dahmani, K.; Hasan, N.; Galjaard, G.; Kruithof, J.; Van Loosdrecht, M. Phosphate limitation to control biofouling. Water Res. 2010, 44, 3454-3466. [CrossRef] [PubMed]

5. Araújo, P.A.; Mergulhão, F.; Melo, L.; Simões, M. The ability of an antimicrobial agent to penetrate a biofilm is not correlated with its killing or removal efficiency. Biofouling 2014, 30, 675-683. [CrossRef]

6. Xiong, Y.; Liu, Y. Biological control of microbial attachment: A promising alternative for mitigating membrane biofouling. Appl Microbiol Biotechnol 2010, 86, 825-837. [CrossRef]

7. Singer, A.C.; Shaw, H.; Rhodes, V.; Hart, A. Review of antimicrobial resistance in the environment and its relevance to environmental regulators. Front. Microbiol. 2016, 7, 1728. [CrossRef] 
8. Khairnar, S.; Shinde, S.; Shrivastava, V. A Short Review on the Improvement of Antimicrobial Activity by Metal and Nonmetal Doping in Nanoscale Antimicrobial Materials. J. Nanomedicine Biotherapeutic Discov. 2019, 9, 163.

9. Qu, X.; Alvarez, P.J.; Li, Q. Applications of nanotechnology in water and wastewater treatment. Water Res. 2013, 47, 3931-3946. [CrossRef]

10. Akbar, A.; Sadiq, M.B.; Ali, I.; Muhammad, N.; Rehman, Z.; Khan, M.N.; Muhammad, J.; Khan, S.A.; Rehman, F.U.; Anal, A.K. Synthesis and antimicrobial activity of zinc oxide nanoparticles against foodborne pathogens Salmonella typhimurium and Staphylococcus aureus. Biocatal. Agric. Biotechnol. 2019, 17, 36-42. [CrossRef]

11. Azizi-Lalabadi, M.; Ehsani, A.; Divband, B.; Alizadeh-Sani, M. Antimicrobial activity of Titanium dioxide and Zinc oxide nanoparticles supported in 4A zeolite and evaluation the morphological characteristic. Scientific reports 2019, 9, 1-10. [CrossRef] [PubMed]

12. Benyahia, F.; O'Neill, K. Enhanced voidage correlations for packed beds of various particle shapes and sizes. Part. Sci. Technol. 2005, 23, 169-177. [CrossRef]

13. Emami-Karvani, Z.; Chehrazi, P. Antibacterial activity of ZnO nanoparticle on Gram-positive and Gram-negative bacteria. Afr. J. Microbiol. Res. 2012, 5, 1368-1373.

14. Jaswal, V.S.; Chaudhary, A.; Thakur, P.; Sharma, D.; Arora, A.K.; Khanna, R.; Tuli, H.S. Chapter 9: ZnO nanoparticle with promising antimicrobial and antiproliferation synergistic properties. In Comprehensive Analytical Chemistry: Engineered Nanomaterials and Phytonanotechnology: Challenges for Plant Sustainability; Verma, S.K., Das, A.K., Eds.; Elsevier: Amsterdam, The Netherlands, 2019; Volume 87, pp. 251-262.

15. Kim, J.S.; Kuk, E.; Yu, K.N.; Kim, J.-H.; Park, S.J.; Lee, H.J.; Kim, S.H.; Park, Y.K.; Park, Y.H.; Hwang, C.-Y.; et al. Antimicrobial effects of silver nanoparticles. Nanomedicine 2007, 3, 95-101. [CrossRef]

16. Le Ouay, B.; Stellacci, F. Antibacterial activity of silver nanoparticles: A surface science insight. Nano Today 2015, 10, 339-354 [CrossRef]

17. Tang, S.; Zheng, J. Antibacterial Activity of Silver Nanoparticles: Structural Effects. Adv. Healthc. Mater. 2018, 7, 1701503. [CrossRef]

18. Yan, X.; He, B.; Liu, L.; Qu, G.; Shi, J.; Hu, L.; Jiang, G. Antibacterial mechanism of silver nanoparticles in Pseudomonas aeruginosa: Proteomics approach. Metallomics 2018, 10, 557-564. [CrossRef]

19. Asri, L.A.T.W.; Crismaru, M.; Roest, S.; Chen, Y.; Ivashenko, O.; Rudolf, P.; Tiller, J.C.; van der Mei, H.C.; Loontjens, T.J.A.; Busscher, H.J. A Shape-Adaptive, Antibacterial-Coating of Immobilized Quaternary-Ammonium Compounds Tethered on Hyperbranched Polyurea and its Mechanism of Action. Adv. Funct. Mater. 2014, 24, 346-355. [CrossRef]

20. Avelelas, F.; Martins, R.; Oliveira, T.; Maia, F.; Malheiro, E.; Soares, A.M.; Loureiro, S.; Tedim, J. Efficacy and ecotoxicity of novel anti-fouling nanomaterials in target and non-target marine species. Mar. Biotechnol. 2017, 19, 164-174. [CrossRef]

21. Chan, A.C.; Bravo Cadena, M.; Townley, H.E.; Fricker, M.D.; Thompson, I.P. Effective delivery of volatile biocides employing mesoporous silicates for treating biofilms. J. R. Soc. Interface 2017, 14, 20160650. [CrossRef] [PubMed]

22. Xue, Y.; Xiao, H.; Zhang, Y. Antimicrobial polymeric materials with quaternary ammonium and phosphonium salts. Int, J. Mol. Sci 2015, 16, 3626-3655. [CrossRef]

23. Wang, J.-L.; Alasonati, E.; Tharaud, M.; Gelabert, A.; Fisicaro, P.; Benedetti, M.F. Flow and fate of silver nanoparticles in small French catchments under different land-uses: The first one-year study. Water Res. 2020, 176, 115722. [CrossRef]

24. Akhtar, K.; Khan, S.A.; Khan, S.B.; Asiri, S.M. Nanomaterials and environmental remediation: A fundamental overview. In Nanomaterials for Environmental Applications and their Fascinating Attributes; Khan, S.B., Asiri, S.M., Akhtar, K., Eds.; Bentham Science Publishers: Sharjah, UAE, 2018; Volume 2, pp. 26-27.

25. Zhang, C.; Cui, F.; Zeng, G.-m.; Jiang, M.; Yang, Z.-Z.; Yu, Z.-g.; Zhu, M.-y.; Shen, L.-q. Quaternary ammonium compounds (QACs): A review on occurrence, fate and toxicity in the environment. Sci Total Environ. 2015, 518, 352-362. [CrossRef]

26. Gerba, C.P. Quaternary ammonium biocides: Efficacy in application. Appl. Environ. Microbiol. 2015, 81, 464-469. [CrossRef] [PubMed]

27. García, M.R.; Cabo, M.L. Optimization of E. coli inactivation by benzalkonium chloride reveals the importance of quantifying the inoculum effect on chemical disinfection. Front. Microbiol. 2018, 9, 1259. [CrossRef] [PubMed]

28. Gao, D.; Feng, J.; Ma, J.; Lü, B.; Jia, X. Zinc oxide sol-containing diallylmethyl alkyl quaternary ammonium salt synthesized by sol-gel process: Characterization and properties. J. Text. Inst. 2015, 106, 593-600. [CrossRef]

29. Muhammad, S.; Siddiq, M.; Niazi, J.H.; Qureshi, A. Role of quaternary ammonium compound immobilized metallic graphene oxide in PMMA/PEG membrane for antibacterial, antifouling and selective gas permeability properties. Polym. Bull. 2018, 75, 5695-5712. [CrossRef]

30. Choi, J.; Han, Y.; Park, S.; Park, J.; Kim, H. Pore characteristics and hydrothermal stability of mesoporous silica: Role of oleic acid. J. Nanomater. 2014, 2014, 86. [CrossRef]

31. She, X.; Chen, L.; Li, C.; He, C.; He, L.; Kong, L. Functionalization of hollow mesoporous silica nanoparticles for improved 5-FU loading. J. Nanomater. 2015, 16, 108. [CrossRef]

32. Zhao, W.; Chen, H.; Li, Y.; Li, L.; Lang, M.; Shi, J. Uniform rattle-type hollow magnetic mesoporous spheres as drug delivery carriers and their sustained-release property. Adv. Func Mater. 2008, 18, 2780-2788. [CrossRef]

33. Liu, J. Multilayered PEI-based Films for CO2 Adsorption and Diffusion. MSc diss., University of Akron. 2013. Available online: http:/ / rave.ohiolink.edu/etdc/view?acc_num=akron1367839488 (accessed on 15 October 2020). 
34. Ribena, D. Dopamine modification of interfaces between polymers and metals. Ph.D. Thesis, Technische Universiteit Eindhoven, Eindhoven, The Netherlands, 2012.

35. Padhye, L.; Luzinova, Y.; Cho, M.; Mizaikoff, B.; Kim, J.-H.; Huang, C.-H. PolyDADMAC and dimethylamine as precursors of N-nitrosodimethylamine during ozonation: Reaction kinetics and mechanisms. Environ. Sci. Technol. 2011, 45, 4353-4359. [CrossRef]

36. Park, S.-H.; Wei, S.; Mizaikoff, B.; Taylor, A.E.; Favero, C.; Huang, C.-H. Degradation of amine-based water treatment polymers during chloramination as N-nitrosodimethylamine (NDMA) precursors. Environ. Sci. Technol. 2009, 43, 1360-1366. [CrossRef] [PubMed]

37. Hassan, K.; Elbagoury, M. Antimicrobial activity of some biocides against microorganisms isolated from a shared student kitchen. Rasayan, J. Chem. 2018, 11, 238-244.

38. Drugeon, H.B.; Juvin, M.-E.; Caillon, J.; Courtieu, A.-L. Assessment of formulas for calculating critical concentration by the agar diffusion method. Antimicrob. Agents Chemother. 1987, 31, 870-875. [CrossRef] [PubMed]

39. Cooper, K.E. Chapter 1: The Theory of Antibiotic Inhibition Zones. In Analytical Microbiology; Kavanagh, F., Ed.; Academic Press: London, UK, 1972; Volume 2, pp. 13-30.

40. Lee, D.; Cohen, R.E.; Rubner, M.F. Antibacterial properties of Ag nanoparticle loaded multilayers and formation of magnetically directed antibacterial microparticles. Langmuir 2005, 21, 9651-9659. [CrossRef] [PubMed]

41. Green, J.-B.D.; Fulghum, T.; Nordhaus, M.A. A review of immobilized antimicrobial agents and methods for testing. Biointerphases 2011, 6, MR13-MR28. [CrossRef]

42. Murray, P.R. The clinician and the microbiology laboratory. In Mandell, Douglas, and Bennett's Principles and Practice of Infectious Diseases; Elsevier: Amsterdam, The Netherlands, 2015; Volume 1, pp. 191-223.

43. Zhao, P.; Li, J.; Wang, Y.; Jiang, H. Broad-spectrum antimicrobial activity of the reactive compounds generated in vitro by Manduca sexta phenoloxidase. Insect Biochemi Mol. Biol 2007, 37, 952-959. [CrossRef]

44. Iqbal, Z.; Lai, E.P.; Avis, T.J. Antimicrobial effect of polydopamine coating on Escherichia coli. J. Mater. Chem. 2012, 22, 21608-21612. [CrossRef]

45. Capita, R.; Vicente-Velasco, M.; Rodríguez-Melcón, C.; García-Fernández, C.; Carballo, J.; Alonso-Calleja, C. Effect of low doses of biocides on the antimicrobial resistance and the biofilms of Cronobacter sakazakii and Yersinia enterocolitica. Sci. rep. 2019, 9, 1-12. [CrossRef]

46. Grant, D.; Bott, T. Biocide dosing strategies for biofilm control. Heat Transf. Eng. 2005, 26, 44-50. [CrossRef]

47. Pazos-Ortiz, E.; Roque-Ruiz, J.H.; Hinojos-Márquez, E.A.; López-Esparza, J.; Donohué-Cornejo, A.; Cuevas-González, J.C.; Espinosa-Cristóbal, L.F.; Reyes-López, S.Y. Dose-dependent antimicrobial activity of silver nanoparticles on polycaprolactone fibers against gram-positive and gram-negative bacteria. J. Nanomater. 2017, 6, 1-9. [CrossRef]

48. Ferreira, C.; Pereira, A.; Pereira, M.; Melo, L.; Simões, M. Physiological changes induced by the quaternary ammonium compound benzyldimethyldodecylammonium chloride on Pseudomonas fluorescens. J. Antimicrob. Chemother. 2011, 66, 1036-1043. [CrossRef]

49. Rosenberg, M.; Azevedo, N.F.; Ivask, A. Propidium iodide staining underestimates viability of adherent bacterial cells. Sci. Rep. 2019, 9, 1-12. [CrossRef]

50. Davey, H.M.; Hexley, P. Red but not dead? Membranes of stressed Saccharomyces cerevisiae are permeable to propidium iodide. Environ. Microbiol. 2011, 13, 163-171. [CrossRef] [PubMed]

51. Kirchhoff, C.; Cypionka, H. Propidium ion enters viable cells with high membrane potential during live-dead staining. J. Microbiol. Methods 2017, 142, 79-82. [CrossRef] [PubMed]

52. Shi, L.; Günther, S.; Hübschmann, T.; Wick, L.Y.; Harms, H.; Müller, S. Limits of propidium iodide as a cell viability indicator for environmental bacteria. Cytometry Part. A 2007, 71, 592-598. [CrossRef]

53. Emerson, J.B.; Adams, R.I.; Román, C.M.B.; Brooks, B.; Coil, D.A.; Dahlhausen, K.; Ganz, H.H.; Hartmann, E.M.; Hsu, T.; Justice, N.B. Schrödinger's microbes: Tools for distinguishing the living from the dead in microbial ecosystems. Microbiome 2017, 5, 86. [CrossRef]

54. Lu, G.; Wu, D.; Fu, R. Studies on the synthesis and antibacterial activities of polymeric quaternary ammonium salts from dimethylaminoethyl methacrylate. React. Funct. Polym. 2007, 67, 355-366. [CrossRef]

55. Owusu-Adom, K.; Guymon, C.A. Photopolymerization kinetics of poly (acrylate)-clay composites using polymerizable surfactants. Polymer 2008, 49, 2636-2643. [CrossRef]

56. He, W.; Zhang, Y.; Li, J.; Gao, Y.; Luo, F.; Tan, H.; Wang, K.; Fu, Q. A novel surface structure consisting of contact-active antibacterial upper-layer and antifouling sub-layer derived from gemini quaternary ammonium salt polyurethanes. Sci. Rep. 2016, 6, 1-9. [CrossRef]

57. Ho, C.H.; Tobis, J.; Sprich, C.; Thomann, R.; Tiller, J.C. Nanoseparated polymeric networks with multiple antimicrobial properties. Adv. Mater. 2004, 16, 957-961. [CrossRef]

58. Sui, Y.; Gao, X.; Wang, Z.; Gao, C. Antifouling and antibacterial improvement of surface-functionalized poly (vinylidene fluoride) membrane prepared via dihydroxyphenylalanine-initiated atom transfer radical graft polymerizations. J. Membr. Sci. 2012, 394, 107-119. [CrossRef]

59. Andrade del Olmo, J.; Ruiz Rubio, L.; Saez Martinez, L.; Perez-Alvarez, V.; Vilas Vilela, J.L. Antibacterial coatings for improving the performance of biomaterials. Coatings 2020, 10, 139. [CrossRef] 
60. Bieser, A.M.; Tiller, J.C. Mechanistic considerations on contact-active antimicrobial surfaces with controlled functional group densities. Macromol. Biosci. 2011, 11, 526-534. [CrossRef]

61. Hoque, J.; Akkapeddi, P.; Yadav, V.; Manjunath, G.B.; Uppu, D.S.; Konai, M.M.; Yarlagadda, V.; Sanyal, K.; Haldar, J. Broad spectrum antibacterial and antifungal polymeric paint materials: Synthesis, structure-activity relationship, and membrane-active mode of action. ACS Appl. Mater. Interfaces 2015, 7, 1804-1815. [CrossRef]

62. Ricardo, S.I.d.C. Antimicrobial strategies to prevent catheters-associated medical infections. Ph.D. Thesis, Universidade de Lisboa, Lisbon, Portugal, 2017.

63. Amgoth, C.; Phan, C.; Banavoth, M.; Rompivalasa, S.; Tang, G. Polymer Properties: Functionalization and Surface Modified Nanoparticles. In Role of Novel Drug Delivery Vehicles in Nanobiomedicine; IntechOpen: London, UK, 2019.

64. Tuson, H.H.; Weibel, D.B. Bacteria-surface interactions. Soft. matter. 2013, 9, 4368-4380. [CrossRef]

65. Brunauer, S.; Emmett, P.H.; Teller, E. Adsorption of Gases in Multimolecular Layers. J. Am. Chem. Soc. 1938, 60, 309-319. [CrossRef]

66. Barrett, E.P.; Joyner, L.G.; Halenda, P.P. The Determination of Pore Volume and Area Distributions in Porous Substances. I. Computations from Nitrogen Isotherms. J. Am. Chem. Soc. 1951, 73, 373-380. [CrossRef]

67. Reed, R.; Reed, G. “Drop plate” method of counting viable bacteria. Can. J. Res. 1948, 26, 317-326. [CrossRef]

68. Simoes, M.; Pereira, M.O.; Vieira, M. Validation of respirometry as a short-term method to assess the efficacy of biocides. Biofouling 2005, 21, 9-17. [CrossRef] 